\title{
Effect of Burning, Cropping and Synthetic Microbial Community Inoculation on Soil Enzyme Activities in 5 Year Jhum Cycle
}

\author{
Carolyn Zothansiami* and Dwipendra Thakuria
}

\author{
College of Post Graduate Studies in Agricultural Sciences, Central Agricultural University \\ (Imphal), Umiam, 796 3103, Meghalaya, India
}

*Corresponding author

\begin{tabular}{|l|}
\hline Ke y w o r d s \\
$\begin{array}{l}\text { Soil enzymes, Soil } \\
\text { process indicator }\end{array}$ \\
\hline Article Info \\
\hline $\begin{array}{l}\text { Accepted: } \\
\text { 20 January } 2020 \\
\text { Available Online: } \\
\text { 10 February } 2020\end{array}$ \\
\hline
\end{tabular}

\section{A B S T R A C T}

Terrestrial ecosystems consist of above- and below-ground components that interact to influence community- and ecosystem-level processes and properties. Soils act as the most important medium between these linkages. These input-output systems influence the soil physico-chemical conditions, diversity and activity of soil biota that are responsible for innumerable processes that occur in the soil. Micro-organisms are the main source of enzymes in soils and a large group of other enzymes are also secreted by the plants in their rhizospheric zone. The composition of soil microbial communities strongly affects the potential of a soil for enzyme-mediated substrate catalysis that determine the soil quality and catalyzes the biochemical processes important in soil functioning such as nutrient mineralization, cycling of nutrients like $\mathrm{N}, \mathrm{P}, \mathrm{S}$ and other essential metals, decomposition and formation of soil organic matter. Soil microbiota and enzymes are sensitive to any external disturbances thus serve as a good indicator for soil quality, changes in any land management as well as indirect assessment of the activity of a specific group of microorganisms in the soil. Due to indigenous shifting cultivation (slash and burn practices) on hill slopes there is mass loss of above-ground biodiversity and thereby breakdown of linkages between aboveand below-ground communities, which may lead to alteration of the mechanism of relationship between functional microbial groups and soil processes.. Burning had significant negative effect on the activity of DHA, GSA, PHA, except ASA indicating higher activity in burnt soil. Introduction of rice crop had significant positive influence on the activity of soil enzymes and soil process indicators. There was significant positive interaction on burning and cropping on soil enzymes activities soil process indicators. There was a significant difference in the activity of soil enzymes and soil process indicators among the microbial inoculants treatment soil process indicators. There was significant positive interaction between burnt and microbial inoculants or cropping and microbial inoculants. 


\section{Introduction}

Soils are known to house the most diverse microbial communities (Nannipieri et al., 2003; Zhao et al., 2014). Enzyme is released to soil by microbial community, plant, animal upon death and by interaction of plantmicrobes in the rhizosphere (Dick et al., 1994). The enzyme activities are sensitive to any external disturbances. Due to their fast response to environmental condition changes and disturbances, enzymatic activities have been widely used as sensitive indicators of alterations in soil microbial function during invasive processes (Nannipieri et al., 1990; Allison et al., 2006) or litter decomposition nutrient cycling and indirect assessment of the activity of a specific group of micro-organism in the soil (Hofrichter, 2002; Baldrain, 2009; Burns et al., 2013; Kotroczó et al., 2014). Therefore, we can say that an array of soil enzymes produced by the diverse groups of microbes act as an indicator of biological soil processes (Veres et al., 2013; Baldrian, 2009; Haifang et al., 2013).

Since time immemorial jhumming (predominant farming practice) is practices by the farmers of Northeastern Hill States of India. This jhum farming is known for destruction of the above-ground biomass through slash and burn activities followed by cropping in burnt lands. This may lead to the alteration of soil microbial communities structure and diversity who are the drivers of major ecosystem processes such as nutrient cycling (van der Heijden et al., 2008; Batten et al., 2006), bioremediation (Gilbert et al., 2012), plant health (Lugtenberg and Kamilova, 2009) and organic matter decomposition and formation (Veres et al., 2013; Baldrian, 2009; Haifang et al., 2013 and Burns et al., 2013). Such disruptions in the above-ground and below-ground biota relationship may trigger the ecological imbalances in soils of jhum agroecosystems.
In order to restore the productivity of Jhum soils, microbial inoculation may be one of the low-cost ecofriendly ways of restoring soil processes. However, there is lack of scientific evidences on how burning event followed by cropping in burnt soils impacted the soil microbial functional groups and thereby effect of soil processes. As 5 year Jhum cycle is most abundant in North Eastern Hill States of India, this study investigated the effect of burnt and unburnt soils of 5 year Jhum cycle in presence or absence of crop (jhum rice) on soil enzyme activities. Besides, the inoculation effect of synthetic microbial functional groups ( $\mathrm{N}_{2}$-fixers group, phosphate solubilizers group, cellulose degrader group and soil fungal group) was also studied under burnt or unburnt soils in presence or absence of jhum rice crop.

\section{Materials and Methods}

\section{Description of sampling site}

Five (5) years jhum cycles from Muallungthu village Aizawl district Mizoram was selected as a study area which lies between $23^{0} 36.279^{\prime}$ $\mathrm{N}$ latitude and $92^{\circ} 42.909^{\prime} \mathrm{E}$ Longitude at altitude of $841-857 \mathrm{~m}$ above mean sea level. The study areas experience wet, warm and humid tropical climate with annual rainfall from 1800 to $2600 \mathrm{~mm}$.

\section{Soil sampling and processing for microcosm experiment}

From the identified 5 years jhum cycle soils at a depth of 0 to $15 \mathrm{~cm}$ of was collected in bulk a day before burning the slash biomass. Next day after burning the biomass and before sowing of seeds bulk soil at a depth of 0 to 15 $\mathrm{cm}$ was collected. This bulk soils was used for conducting mesocosm experiment at research farm of College of Post Graduate Studies, Central Agricultural University, Umiam, Meghalaya $\left(91^{\circ} 54.643^{\prime \prime}\right.$ E, 2540.929" N 
latitude and $950 \mathrm{~m}$ above mean sea level). The soil samples collected before burning the slashed biomass represent unburnt soils and soil samples collected after burning represent as burnt soils. The collected soils from burnt and unburnt situations were allowed to pass through $2 \mathrm{~mm}$ sieve separately and removed all visible fine roots and other organic debris and keep ready for the mesocosm experiment. A series of pots were arranged in 4 groups. In two groups i.e. burnt and unburnt soil jhum rice was grown where in the other 2 groups no crop was grown.

The pot were filled with $4.0 \mathrm{~kg}$ sieved soil and used for growing rice crop and no rice crop was sown in pot filled with $2 \mathrm{~kg}$ sieved soil. The bulk density of the pot soil was adjusted based on weight by volume basis to mimic the bulk density in field situations. Only after the pot soil mimic bulk density of the field situation functional microbial groups were inoculated. Soil moisture in the pot was maintained at field capacity throughout the experimental period. Just before inoculating the functional microbial groups a soil sample of approximately $100 \mathrm{gm}$ was collected from each groups and store the soil sample at $4^{0} \mathrm{C}$ for further analysis

\section{Treatment details}

Each group of pot experiment was treated with different bacterial functional groups and a synthetic fungal community. Three functional bacterial groups are: (1) $\mathrm{N}_{2^{-}}$fixers, (2) Phosphate Solubilising Bacteria (PSB), and (3) Cellulose Degrading Bacteria (CDB). All together six (6) treatment combinations was imposed viz. T1: 5 strains PSB +5 strains synthetic fungal community, T2: 5 strains $\mathrm{N}_{2-}$ fixers +5 strains synthetic fungal community, T3: 5 strains $\mathrm{CDB}+5$ strains synthetic fungal community, T4: 5 strains each of PSB $+\mathrm{N}_{2-}$ fixers $+\mathrm{CDB}+5$ strains synthetic fungal community, T5: No bacteria +5 strains synthetic fungal community and T6: No inoculation.

Upland rice variety Bahlum-1 was used as a test crop. In each pot rice seeds (3 seeds per pot) was sown where rice is to be grown and no seeds were sown where only $2 \mathrm{~kg}$ of soil were kept

\section{Soil analysis}

\section{Soil biochemical properties}

Soil biochemical properties were determined as per the standard procedures described in Page et al., (1982).

\section{Arylsulphatase Activity (ASA)}

Arylsulphatase was measured following the principle described by Tabatabai and Bremner, (1970) which was based on determination of $p$-nitrophenol released after incubation of soil with $p$-nitrophenyl sulphate (PNS). Arylsulphatase enzyme activity was expressed as $\mu \mathrm{g}$ (PNP) $\mathrm{g}^{-1}$ (dw) soil $\mathrm{h}^{-1}$.

\section{$\beta$-glucosidase Activity (GSA)}

$\beta$-glucosidase was determined following the assay outlined by Tabatabai (1982) and Eivazi and Tabatabai (1988). $\beta$-glucosidase enzyme activity was expressed as $\mu \mathrm{g}$ (PNP) $\mathrm{g}^{-1}$ (dw) soil $\mathrm{h}^{-1}$.

\section{Dehydrogenase Activity (DHA)}

Dehydrogenase was determined in air dried soil samples as per the method described by Casida et al., (1964). DHA was expressed as $\mu \mathrm{g}$ (TPF) $\mathrm{g}^{-1}(\mathrm{dw})$ soil $^{-1}$.

\section{Phosphomonoesterase Activity (PHA)}

Phosphomonoestarase determination following the protocol described by Tabatabai and Bremner (1969). Phosphomonoestarase enzyme activity was expressed as $\mu \mathrm{g}$ (PNP) $\mathrm{g}^{-1}$ (dw) soil $\mathrm{h}^{-1}$. 


\section{Results and Discussion}

The response of soil bacterial community to application of synthetic microbial community (synthetic PSB community, synthetic $\mathrm{N}_{2}$-fixer community, synthetic CDB community and synthetic fungal community) in presence or absence of rice crop under both burnt and unburnt soils of 5 year jhum cycle was studied in mesocosm experiment. The change in soil enzymes and biochemical properties was studied at 10, 45, 90 and 120 days of rice plant growth.

Effect of burning, cropping and microbial inoculation on soil enzymes activity as an indicator of soil processes

Soil enzymes activities at 10 days of rice plant growth

The soil enzymes such as DHA, GSA, ASA and PHA were strongly influence by the burning, cropping and synthetic microbial inoculation (Table 1). The activities of DHA, GSA, and PHA were decrease in burnt soil where as a slight increase in the activity of ASA was found in burnt soil.

Cropping had a great influence to soil enzymes which shows the enzymes activity increase in presence of rice crop than the bulk soils. Each of the microbial inoculation responds was differ to each enzymes activity. The inoculation of synthetic $\mathrm{N}_{2}$ fixer had a greater impact to soil DHA, synthetic CDB had greater impact to GSA, synthetic PSB inoculants affect the PHA and synthetic fungi inoculation greater impact at ASA at 10 days of rice plant growth.

Soil enzymes activities at $\mathbf{4 5}$ days of rice plant growth

The soil enzymes such as DHA, GSA, ASA and PHA were strongly influence by the burning, cropping and synthetic microbial inoculation (Table 2). The activities of DHA, GSA, and PHA were decrease in burnt soil where as a slight increase in the activity of ASA was found in burnt soil. Cropping had a great influence to soil enzymes which shows the enzymes activity increase in presence of rice crop than the bulk soils. Each of the microbial inoculation responds to soil enzymes activity differently. The inoculation of synthetic CDB + Fungi had impact to soil DHA, GSA and ASA enzyme activities. The inoculations of synthetic PSB + fungi effect the PHA activity at 45 days of rice plant growth.

Soil enzymes activities at 90 days of rice plant growth

The soil enzymes such as DHA, GSA, ASA and PHA were strongly influence by the burning activity (Table 3). The activities of DHA, GSA, and PHA were decrease in burnt soil where there was a slight increased in the activity of ASA in burnt soil.

Interestingly the activities of all the enzymes were found higher in soils where rice crop was grown as compared to bulk soils. Each of the microbial inoculation responds to soil enzymes activity differently. The soil inoculation of synthetic PSB +synthetic $\mathrm{N}_{2}$ fixer + synthetic CDB+ synthetic fungi had a greater impact to soil DHA, inoculation of synthetic CDB + Fungi effect the GSA, inoculations of synthetic PSB + fungi influence the PHA activity and synthetic $\mathrm{N}_{2}$ fixer + fungi greater impact to ASA at 90 days of rice plant growth.

Soil enzymes activities at $\mathbf{1 2 0}$ days of rice plant growth

The soil enzymes such as DHA, GSA, ASA and PHA were strongly influence by the burning activity (Table 4). 
Table.1 Table 1: Interaction effect of burning, cropping and synthetic microbial communities on soil enzyme activities in 5 years Jhum cycle at 10 days growth of rice plant

\begin{tabular}{|c|c|c|c|c|}
\hline \multirow{3}{*}{$\begin{array}{l}\text { Treatments } \\
\text { Jhumming (J) }\end{array}$} & \multirow{2}{*}{$\begin{array}{c}\text { DHA } \\
\mu \mathrm{g} \mathrm{TPF}^{-1}(\text { dry }) \text { soil }^{-1}\end{array}$} & GSA & PHA & ASA \\
\hline & & \multicolumn{3}{|c|}{$\mu \mathrm{g} \mathrm{PNP}_{\mathrm{g}}^{-1}$ (dry) soil $\mathrm{h}^{-1}$} \\
\hline & & & & \\
\hline Burnt & $0.51 b$ & $365.8 b$ & $560.4 \mathrm{~b}$ & $74.06 \mathrm{~b}$ \\
\hline Unburnt & $1.39 \mathrm{a}$ & $383.4 \mathrm{a}$ & $612.1 \mathrm{a}$ & $104.4 \mathrm{a}$ \\
\hline \multicolumn{5}{|l|}{ Cropping ( C ) } \\
\hline With rice & $0.90 \mathrm{~b}$ & $340.9 b$ & $571.9 \mathrm{~b}$ & $90.71 \mathrm{a}$ \\
\hline Without rice & $0.99 a$ & $408.2 \mathrm{a}$ & $600.6 \mathrm{a}$ & $87.80 \mathrm{~b}$ \\
\hline \multicolumn{5}{|l|}{ Microbial Inoculation (MI) } \\
\hline PSB + Fungi & $1.1 \mathrm{~b}$ & $428.1 b$ & $646.0 \mathrm{~b}$ & $94.40 \mathrm{~b}$ \\
\hline $\mathrm{N}_{2}$ fixer + Fungi & $1.2 \mathrm{a}$ & $384.6 \mathrm{c}$ & $626.7 \mathrm{c}$ & $85.15 \mathrm{c}$ \\
\hline CDB + Fungi & $1.0 \mathrm{c}$ & $452.4 \mathrm{a}$ & $705.4 \mathrm{a}$ & $86.07 \mathrm{c}$ \\
\hline $\mathrm{PSB}+\mathrm{N}_{2}$ fixer $+\mathrm{CDB}+$ Fungi & $0.8 \mathrm{~d}$ & $319.3 e$ & $529.7 \mathrm{e}$ & $83.69 \mathrm{c}$ \\
\hline Fungi & $0.7 \mathrm{e}$ & $342.7 d$ & $547.0 \mathrm{~d}$ & $101.3 \mathrm{a}$ \\
\hline No inoculation (control) & $0.6 f$ & $320.3 d$ & $462.7 f$ & $84.88 \mathrm{c}$ \\
\hline \multicolumn{5}{|l|}{ Interactions } \\
\hline $\mathbf{J} * \mathbf{C}$ & $* *$ & $* *$ & $* *$ & $* *$ \\
\hline $\mathbf{J} * \mathbf{M I}$ & $* *$ & $* *$ & $* *$ & $* *$ \\
\hline $\mathbf{C} * \mathbf{M I}$ & $* *$ & $* *$ & $* *$ & $* *$ \\
\hline $\mathbf{J} * \mathbf{C} * \mathbf{M I}$ & $* *$ & $* *$ & $* *$ & $* *$ \\
\hline
\end{tabular}


Table.2 Interaction effect of burning, cropping and synthetic microbial communities on soil enzyme activities in 5 years Jhum cycle at 45 days growth stage of rice plant

\begin{tabular}{|c|c|c|c|c|}
\hline \multirow{3}{*}{$\begin{array}{l}\text { Treatments } \\
\text { Jhumming (J) }\end{array}$} & \multirow{2}{*}{$\begin{array}{c}\text { DHA } \\
\mu \mathrm{g} \text { TPF } \mathrm{g}^{-1} \text { (dry) soil } \mathrm{h}^{-1}\end{array}$} & GSA & PHA & ASA \\
\hline & & \multicolumn{3}{|c|}{$\mu \mathrm{g}$ PNP g $^{-1}$ (dry) soil $\mathrm{h}^{-1}$} \\
\hline & & & & \\
\hline Burnt & $08.30 \mathrm{~b}$ & $321.6 \mathrm{a}$ & $524.8 \mathrm{a}$ & $110.8 b$ \\
\hline Unburnt & $16.10 \mathrm{a}$ & $306.1 b$ & $502.2 b$ & $118.3 \mathrm{a}$ \\
\hline \multicolumn{5}{|l|}{ Cropping ( C ) } \\
\hline With rice & $14.48 \mathrm{a}$ & $296.7 b$ & $520.6 \mathrm{a}$ & $131.2 \mathrm{a}$ \\
\hline Without rice & $09.92 b$ & $330.9 a$ & $506.5 b$ & $98.09 \mathrm{~b}$ \\
\hline \multicolumn{5}{|l|}{ Microbial Inoculation (MI) } \\
\hline PSB + Fungi & $12.5 \mathrm{c}$ & $298.3 d$ & $559 . \mathrm{a}$ & $116.4 \mathrm{bc}$ \\
\hline $\mathrm{N}_{2}$ fixer + Fungi & $14.1 \mathrm{~b}$ & $260.1 \mathrm{e}$ & $511.3 \mathrm{~d}$ & $109.7 \mathrm{c}$ \\
\hline CDB + Fungi & $15.7 \mathrm{a}$ & $433.3 \mathrm{a}$ & $543.4 \mathrm{a}$ & $130.1 \mathrm{a}$ \\
\hline $\mathrm{PSB}+\mathrm{N}_{2}$ fixer $+\mathrm{CDB}+$ Fungi & $10.8 \mathrm{~d}$ & $337.5 b$ & $436.3 f$ & $116.7 \mathrm{bc}$ \\
\hline Fungi & $10.0 \mathrm{~d}$ & $308.6 \mathrm{c}$ & $527.2 \mathrm{c}$ & $121.0 \mathrm{~b}$ \\
\hline No inoculation (control) & $10.0 \mathrm{~d}$ & $245.2 f$ & $503.3 \mathrm{e}$ & $93.6 \mathrm{~d}$ \\
\hline \multicolumn{5}{|l|}{ Interactions } \\
\hline $\mathbf{J} * \mathbf{C}$ & $* *$ & $* *$ & $* *$ & $* *$ \\
\hline $\mathbf{J} * \mathbf{M I}$ & $* *$ & $* *$ & $* *$ & $* *$ \\
\hline $\mathrm{C} * \mathrm{MI}$ & $* *$ & $* *$ & $* *$ & $* *$ \\
\hline $\mathbf{J} * \mathbf{C} * \mathbf{M I}$ & $* *$ & $* *$ & $* *$ & $* *$ \\
\hline
\end{tabular}


Table.3 Interaction effect of burning, cropping and synthetic microbial communities on soil enzyme activities in 5 years Jhum cycle at 90 days growth stage of rice plant

\begin{tabular}{|c|c|c|c|c|}
\hline \multirow[t]{2}{*}{ Treatments } & DHA & GSA & PHA & ASA \\
\hline & $\mu \mathrm{g}_{\text {TPF }} \mathrm{g}^{-1}$ (dry) soil $\mathrm{h}^{-1}$ & \multicolumn{3}{|c|}{$\mu \mathrm{g} \mathrm{NP} \mathrm{g}^{-1}$ (dry) soil h${ }^{-1}$} \\
\hline \multicolumn{5}{|l|}{ Jhumming (J) } \\
\hline Burnt & $10.64 b$ & $379.6 b$ & $336.0 \mathrm{~b}$ & $47.73 b$ \\
\hline Unburnt & $18.86 \mathrm{a}$ & $396.5 \mathrm{a}$ & 497.1a & $102.3 \mathrm{a}$ \\
\hline \multicolumn{5}{|l|}{ Cropping ( C ) } \\
\hline With rice & $17.97 \mathrm{a}$ & $405.1 \mathrm{a}$ & $402.8 b$ & $88.70 \mathrm{a}$ \\
\hline Without rice & $11.53 b$ & $371.1 b$ & $430.3 \mathrm{a}$ & $61.37 b$ \\
\hline \multicolumn{5}{|l|}{ Microbial Inoculation (MI) } \\
\hline PSB + Fungi & $16.1 \mathrm{c}$ & $426.4 \mathrm{c}$ & $420.1 \mathrm{c}$ & $66.2 d$ \\
\hline $\mathbf{N}_{2}$ fixer + Fungi & $16.8 \mathrm{bc}$ & $345.6 \mathrm{~d}$ & $363.6 \mathrm{e}$ & $82.0 \mathrm{a}$ \\
\hline CDB + Fungi & $71.5 b$ & $304.3 \mathrm{f}$ & $461.3 \mathrm{a}$ & $76.7 b$ \\
\hline PSB $+\mathbf{N}_{2}$ fixer + CDB + Fungi & $18.9 \mathrm{a}$ & $321.0 \mathrm{e}$ & $424.0 \mathrm{~b}$ & $72.3 \mathrm{c}$ \\
\hline Fungi & $10.7 d$ & $443.0 \mathrm{~b}$ & $405.1 d$ & $77.1 \mathrm{~b}$ \\
\hline No inoculation (control) & $8.4 \mathrm{e}$ & $488.0 \mathrm{a}$ & $426.0 \mathrm{~b}$ & $75.8 b$ \\
\hline \multicolumn{5}{|l|}{ Interactions } \\
\hline $\mathbf{J} * \mathbf{C}$ & $* *$ & $* *$ & $* *$ & $* *$ \\
\hline $\mathbf{J} * \mathbf{M I}$ & $* *$ & $* *$ & $* *$ & $* *$ \\
\hline $\mathbf{C} * \mathbf{M I}$ & $* *$ & $* *$ & $* *$ & $* *$ \\
\hline $\mathbf{J} * \mathbf{C} * \mathbf{M I}$ & $* *$ & $* *$ & $* *$ & $* *$ \\
\hline
\end{tabular}


Table.4 Interaction effect of burning, cropping and synthetic microbial communities on soil enzyme activities in 5 years Jhum cycle at 120 days growth stage of rice plant

\begin{tabular}{|c|c|c|c|c|}
\hline \multirow[t]{2}{*}{ Treatments } & DHA & GSA & PHA & ASA \\
\hline & $\mu \mathrm{g}$ TPF $\mathrm{g}^{-1}$ (dry) soil $\mathrm{h}^{-1}$ & \multicolumn{3}{|c|}{$\mu \mathrm{g} \mathrm{NP} \mathrm{g}^{-1}$ (dry) soil h${ }^{-1}$} \\
\hline \multicolumn{5}{|l|}{ Jhumming (J) } \\
\hline Burnt & $07.475 b$ & $308.9 b$ & 351.397 & $68.12 b$ \\
\hline Unburnt & $20.356 a$ & $425.2 \mathrm{a}$ & 323.021 & $81.54 \mathrm{a}$ \\
\hline \multicolumn{5}{|l|}{ Cropping ( C ) } \\
\hline With rice & $16.151 \mathrm{a}$ & $355.6 b$ & 514.652 & $86.02 \mathrm{a}$ \\
\hline Without rice & $11.680 \mathrm{~b}$ & $378.6 \mathrm{c}$ & 159.766 & $63.64 b$ \\
\hline \multicolumn{5}{|l|}{ Microbial Inoculation (MI) } \\
\hline PSB + Fungi & $15.8 \mathrm{a}$ & $327.0 f$ & $336.1 \mathrm{c}$ & $60.4 \mathrm{e}$ \\
\hline $\mathrm{N}_{2}$ fixer + Fungi & $15.3 \mathrm{a}$ & $337.1 \mathrm{e}$ & $296.8 \mathrm{e}$ & $76.5 \mathrm{bc}$ \\
\hline CDB + Fungi & $13.1 \mathrm{~b}$ & $371.7 \mathrm{c}$ & $350.2 b$ & $83.6 \mathrm{a}$ \\
\hline PSB $+\mathrm{N}_{2}$ fixer + CDB + Fungi & $13.7 b$ & $400.0 \mathrm{~b}$ & $367.6 \mathrm{a}$ & $75.5 \mathrm{bc}$ \\
\hline Fungi & $13.3 b$ & $403.3 \mathrm{a}$ & $349.6 b$ & $78.6 b$ \\
\hline No inoculation (control) & $12.2 \mathrm{c}$ & $363.3 d$ & $322.7 \mathrm{~d}$ & $74.4 d$ \\
\hline \multicolumn{5}{|l|}{ Interactions } \\
\hline $\mathbf{J} * \mathbf{C}$ & $* *$ & $* *$ & $* *$ & $* *$ \\
\hline $\mathbf{J} * \mathbf{M I}$ & $* *$ & $* *$ & $* *$ & $* *$ \\
\hline $\mathbf{C} * \mathbf{M I}$ & $* *$ & $* *$ & $* *$ & $* *$ \\
\hline $\mathbf{J} * \mathbf{C} * \mathbf{M I}$ & $* *$ & $* *$ & $* *$ & $* *$ \\
\hline
\end{tabular}


The activities of DHA, GSA, and PHA were decrease in burnt soil where the activity of ASA was slightly increased in burnt soil. Interestingly the activities of all the enzymes were found higher in soils where rice crop had grown increased and cropping and GSA were taken as an early indicator of soil processes. The microbial inoculation responds was different to each enzymes activity. The inoculation of synthetic $\mathrm{N}_{2}$ fixer had a greater impact to soil DHA, synthetic CDB had greater impact to GSA, synthetic PSB inoculants effect the PHA and synthetic fungi inoculation greater impact at ASA at 120 days of rice plant growth. Each of the microbial inoculation responds to soil enzymes activity differently. The inoculation of synthetic $\mathrm{N}_{2}$ fixer had a greater impact to soil DHA is impacted by inoculations of synthetic PSB + fungi and synthetic $\mathrm{N}_{2}$ fixer + fungi, synthetic fungi had greater impact on GSA, synthetic PSB + synthetic $\mathrm{N}_{2}$ fixer + synthetic CDB+ synthetic fungi inoculants effect the PHA and synthetic CDB + Fungi inoculation had greater impact to ASA at 120 days of rice plant growth.

The interaction between jhumming* cropping; jhumming * microbial innoculation; cropping * microbial inoculation and jhumming * cropping $*$ microbial inoculation were significance at a level $P \leq 0.01$ in $10,45.90,120$ days of rice growing period.

Soil enzymes get reduced as their hydrological enzyme gets disturbed by burning activities. Change in their environment and oxidation of the available compounds by fire also directly affect the microbial activities in soil. Fire change the soil energy pathway which reflects to taxonomic shift in soil microbial communities (Bisset and Parkinson, 1980). The soil enzymes such as DHA, GSA, ASA and PHA were strongly influence by the burning, cropping and synthetic microbial inoculation throughout the rice crop growing season in our investigation. With the consequence of seasonal moisture changes, soil temperature and land management, soil and vegetation conditions the phosphatase activity in soil gets effected (Herbien and Neal, 1990). It also reflects and feedback on community composition (Sinsabaugh et al., 2002). As PHA is directly affected by various factors it was reported that fire affects the enzymes activity which results in decrease of PHA activity in soil after burning (Ajwa et al., 1999). This past findings was concurrent with our present finding PHA enzymes activity decrease in burnt soil in comparison to unburnt soils. The higher amount of PHA in soil with rice plant in comparisons to bulk soil was that when there was $\mathrm{P}$ deficient in a soil plant roots secrete which enhance the solubilisation and remobilization of phosphate in soil and in bulk soil there was no such things which can release the phosphatase enzymes ( Kai et al., 2002; Versaw and Harrison, 2002). PHA enzymes activity was high in soils inoculated with functional PSB + synthetic fungi. Soil microclimate, SOC and the availability of $\mathrm{P}$ in the soil governed phosphatase enzyme and involved in Pcycling (Hamman et al., 2008).

GSA as advanced changes in organic carbon it become a good indicator (Dick, 1994; Wick et al., 1998). Thus, become a good biochemical indicator for measuring ecological changes. In present studies GSA was found to be decrease in burnt soil throughout the rice growing session in our study and a similar results of decrease in GSA activity after burning was reported by (Ajwa et al., 1999: Saplalrinliana et al., 2016 and Lungmuana et al., 2017). Under the influence of rice plant and GSA activity was found higher throughout the rice growing session. The most predominant source of $\beta$-Dglucosidase activity in soils was reported to be Fungi (Hayano and Katami, 1977; Hayano 
and Tubaki, 1985). GSA was found to be highest in soil inoculated with synthethic $\mathrm{CDB}+$ Fungi. The most dominant glucosidase i.e $\beta$-glucosidase was released to the soil largely by plants, animals, fungi and bacteria (Esen, 1993) and this enzyme activity play a fundamental role in release of labile carbon to microorganism as well as $\mathrm{C}$ cycling in large scale (Acosta et al., 2007). CDB being involved in $\mathrm{C}$-cycling this can be the result where highest GSA activity was found in soil inoculated with functional $\mathrm{CDB}+$ synthetic fungi.

The labile cellulose was break down by $\beta$ glucosidase, which degrades the plant cell walls and involves in plant cell tissues decomposition at the first phases. This cell wall decompositions activate the other enzymes such as proteases and phosphatases (Sardans et al., 2008). Glucose as its final product it becomes an important $\mathrm{C}$ energy source to microbes in soil (Esen, 1993). Its sensitivity to land management and soil $\mathrm{pH}$ was reported by (Dick et al., 1996: AcostaMartinez and Tabatabai, 2000; Ndiaye et al., 2000.) and also reflects the past biological activity.

The decrease of DHA in burn soils was observed throughout the rice growing session in comparison with unburnt soils. Our present study was in harmony with the past findings of (Ajwa et al., 1999; Wolińska and Stępniewska, 2012; Lungmuana et al., 2017) who reported the decrease of DHA after burning. Polluted soil with fly ash has lower DHA activity. DHA as an intracellular enzymes it has a close relationship with microbial activity and is often used as an indicator of microbial activity in soil (Dick, 1994.). Both DHA and GSA activity patterns resembled the associated change in $\mathrm{OC}$ as a reflection of change in substrate availability for soil microbial community (Saha et al., 2011; Gispert et al., 2013).
Types and amount of organic matter content (Sarathchandra and Perrott, 1981) and change in soil $\mathrm{pH}$ (Acosta-Martínez and Tabatabai, 2000) contributes the reasons for change in ASA activity. Burning the biomass result in increase in soil $\mathrm{pH}$ which results to changes in ASA activity after burning and a similar change was also reported by (Vong et al., 2003) Microbial biomass in different soil systems is often correlated to the rate of $\mathrm{S}$ immobilisation (Klose and Tabatabai, 1999; Vong et al., 2003). With the introduction of rice crop ASA activity increases in comparison to bulk soil. This is due to the fact that where a crop is grown there was stress of available sulphur content in soil which results in increased secretion of sulphatase to cope up with the ecological demand thus results in higher ASA content in soils where rice crop was grown (Saplalrinliana et al., 2016; Lungmuana et al., 2017).

The possible causes of negative impact of burning on soil enzyme activities are: (1) depletion of hydrolytic enzyme pools due to breakdown of above- and below-ground community (2) sudden reduction in soil biota population and (3) nutrient enrichment in soils after burning reduce the dependency of crop plants on enzyme activities.

In conclusion, burning had significant negative effect on the activity of DHA, GSA, PHA except ASA indicating higher activity in burnt soil. Introduction of rice crop had significant positive influence on the activity of soil enzymes. Introduction of crop in burn soil along with microbial inoculation may positively influenced soil processes as well as crop growth.

\section{References}

Acosta-Martínez, V. and Tabatabai, M.A. (2000). Enzyme activities in a limed agricultural soil. Biol. Fert. Soils, 31: 
85-91.

Acosta-Martinez, V., Cruz, L., Sotomayor, R.D. and Perez-Alegria, L. (2007). Enzyme activities as affected by soil properties and land use in a tropical watershed. Appl. Soil Ecol., 35: 35-45.

Ajwa, H.A., Dell, C.J. and Rice, C.W. (1999). Changes in enzyme activities and microbial biomass of tall grass prairie soil as related to burning and nitrogen fertilization. Soil Biol. Biochem., 31:769-777.

Allison, S.D. (2006) Soil minerals and humic acids alter enzyme stability: implications for ecosystem processes. Biogeochem., 81:361-373

Baldrian, P. (2009). Microbial enzymecatalyzed processes in soils and their analysis. Plant Soil Environ., 55:370 378.

Batten, M.K., Scow, K.M., Davies, M,F., and Harrison, S.P. (2006): Two invasive plants alter soil microbial community composition in serpentine grasslands. Biol. Invas., 8:217-230.

Bisset , J. and Parkinson D (1980) Long term effects of fire on the composition and activity of the soil microflora of a subalpine, coniferous forest. Can J Bot 58:1704-1721

Burns, R.G., De Forest, J.L., Marxsen, J., Sinsabaugh, R.L., Stromberger, M.E., Wallenstein, M.D., Weintraub, M.N. and Zoppini, A. (2013). Soil enzymes in a changing environment: Current knowledge and future directions. Soil Biol. Biochem., 58: 216-234.

Casida, L., Klein, D. and Santoro, T. (1964). Soil Dehydrogenase Activity. Soil Sci., 98: 371-376.

Dick, R.P. (1994). Soil enzyme activities as indicators of soil quality. In: Doran, J.W., Coleman, D.C., Bezdicek, D.F. and Stewart, B.A. (eds) Defining Soil Quality for a Sustainable Environment. Soil Sci. Soc. Am., Madison, Wisconsin, pp. 107-124.

Dick, R.P., Breakwell, D.P.. Turco, R. F. (1996). Soil enzyme activities and biodiversity measurements as integrative microbiological indicators.as indicators of soil quality. Soil Sci. Soc. Am., Madison, Wisconsin, pp. 247.

Eivazi, F. and Tabatabai, M.A. (1988). Glucosidases and galactosidases in soils. Soil Biol. Biochem., 20: 601-606.

Erni, C. (2008). The Concept of indigenous peoples in Asia. A resource book, Copenhagen/Chiang Mai, IWGIA and AIPP

Esen, A. (1993). Beta-glucosidases: overview. In: Esen A (Ed.) Beta- glucosidases and molecular biology. American Chemical Society, Washington, DC, pp. 9-17.

Gilbert, N., Fulthorpe, R., and Kirkwood, A.E. (2012). Microbial diversity, tolerance, and biodegradation potential of urban wetlands with different input regimes. Can J Microbiol., 58: 887897.

Haifang Z., Gang L., Xiaolong S., Dianlin Y., Yujie Li., Jiang Q., Jingni Z. and Shulan Z. (2013). Changes in soil microbial functional diversity under different vegetation restoration patterns for Hulunbeier Sandy Land. Acta Ecologica Sinica, 33: 38-44

Hamman, S.T., Burke, I.C. and Knapp, E.E. (2008). Soil nutrients and microbial activity after early and late season prescribed burns in a Sierra Nevada mixed conifer forest. Forest Ecol. Manag., 256: 367-374.

Hayano, K., and A. Katami. (1977). Extraction of b-glucosidase activity from pea field soil. Soil Biol. Biochem. 9:349-351.

Hayano, K., and K. Tubaki. 1985. Origin and properties of b-glucosidase activity of tomato-field soil. Soil Biol. Biochem. 17:553-557

Herbien, S. A. and Neal, J. L. (1990). Soil pH 
and phosphatase activity. Communications in Soil Science and Plant Analysis, 21:439-456.

Hofrichter M. (2002). Review: Lignin conversion by manganese peroxidase (MnP). Enzy. and Microb. Technol., 30: 454-466

Kai, M., Takazumi, K., Adachi, H., Wasaki, J., Shinano, T. and Osaki, M. (2002). Cloning and characterization of four phosphate transporter cDNAs in tobacco. Plant Sci., 163: 837-846.

Klose, S. and M.A. Tabatabai. (1999). Urease activity of microbial biomass in soils. Soil Biol. Biochem., 31: 205-211.

Kotroczó, Z., Veres, Z., Fekete, I., Krakomperger, Z., Tóth, A.J., Kate, L. and Tóthmérész, B. (2014). Soil enzyme activity in response to long-term organic matter manipulation. Soil Biol. and Biochem., 70: 237-243. doi: 10.1016/j.soilbio.2013.12.028.

Lugtenberg, B.J.J. and Kamilova, F. (2009). Plant growth promoting rhizobacteria. Ann Rev Microbiol., 63:363-383.

Lungmuana, Singh, B.S., Vanthawmliana, Saha, S., Dutta,K.S. Rambuatsaiha, Akoijam R. Singh, R.A. and Boopathi, T.(2017). Impact of secondary forest fallow period on soil microbial biomass carbon and enzyme activity dynamics under shifting cultivation in North Eastern Hill region, India. Catena, 156:10-17.

Nannipieri P, Ascher J, Ceccherini MT, Landi L, Pietramellara G, Renella G (2003) Microbial diversity and soil functions. Eur J Soil Sci 54:655-670.

Nannipieri, P., Grego, S. and Ceccanti, B. (1990). Ecological significance of the biological activity in soils. In: Bollag, J.M. and Stotzky, G. (eds) Soil Biochemistry, Marcel Dekker, New York, pp. 293-355.

Ndiaye, E.L., Sandeno, J.M., McGrath, D. and Dick, R.P. (2000). Integrative biological indicators for detecting change in soil quality. Am. $J$. Alternative Agr., 15: 26-36.

Page, A.L., Miller, R.L. and Keeny, D.R. (1982). Methods of soil analysis. Part-2 chemical and microbiological properties, 2nd edition, Agronomy Monograph, 9: 961-1010, ASA, SSSA, CSSA, Madison.

Saha, S., Chakraborty, D., Lata, Pal. M. and Nagarajan, S. (2011). Impact of elevated $\mathrm{CO} 2$ on utilization of soil moisture and associated soil biophysical parameters in pigeon pea (Cajanas cajan L.). Agric. Ecosyst. Environ., 142:213-221.

Saplalrinliana, H., Thakuria, D., Changkija., S. and Hazarika, S. (2016). Impact of Shifting Cultivation on Litter Accumulation and Properties of Jhum Soils of North East India. J. Indian Soc. Soil Sci., 64:650-1659.

Sardans, J. Penuelas, J. and Estiarte, M. (2008). Changes in soil enzymes related to $\mathrm{C}$ and $\mathrm{N}$ cycle and in soil $\mathrm{C}$ and $\mathrm{N}$ content under prolonged warming and drought in a Mediterranean shrubland. Appl. Soil Ecol., 39:223-235.

Sinsabaugh, R.L., Carreiro, M.M., and Repert, D.A. (2002). Allocation of extracellular enzymatic activity in relation to litter composition, $\mathrm{N}$ deposition, and mass loss. Biogeochemistry, 60:1-24.

Tabatabai M.A. (1982). Soil enzymes, Dehydrogenases. In: Miller, R.H. and Keeney, D.R. (eds) Methods of Soil Analysis, Part 2. Chemical and Microbiolgical Properties. Agronomy

Tabatabai, M.A. and Bremner, J.M. (1969). Use of $p$-nitrophenyl phosphate for assay of soil phosphatase activity. Soil Biol. Biochem., 1: 301-307.

Tabatabai, M.A. and Bremner, J.M. (1970). Arylsulphatase activity of soils. Soil Sci. Soc. Am. J., 34: 225-229. 
van der Heijden, M.G., Bardgett, R.D., and van Straalen, N.M. (2008). The unseen majority: soil microbes as drivers of plant diversity and productivity in terrestrial ecosystems. Ecol Lett., 11: 296-310.

Veres, Z., Kotroczó, Z., Magyaros, K., Tóth, J.A. and Tóthmérész, B. (2013). Dehydrogenase Activity in a Litter Manipulation Experiment in Temperate Forest Soil. Acta Silv. Lign. Hung., 9: 25-33.

Versaw, W.K. and Harrison, M.J. (2002). A Chloroplast Phosphate Transporter, PHT2; 1, Influences Allocation of Phosphate within the Plant and Phosphate-Starvation Responses. Plant Cell, 14: 1751-1766

Vong, P.C., Dedourge, O., Lasserre-Joulin, F. and Guckert, A. (2003). Immobilized-S, microbial biomass $-\mathrm{S}$ and soil arylsulphatase activity in the rhizosphere soil of rape and barley as affected by labile substrate $\mathrm{C}$ and $\mathrm{N}$ additions. Soil Biol. Biochem., 35: 1651-1661.

Wick, B., Kühne, R.F. and Vlek, P.L.G. (1998). Soil microbiological parameters as indicators of soil quality under improved fallow management systems in southwestern Nigeria. Plant Soil, 202: 97-107.

Wolińska, A. and Stępniewska, Z. (2012). Dehydrogenase activity in the soil environment. The John Paul II Catholic University of Lublin, Institute of Biotechnology, Department of Biochemistry and Environmental Chemistry, Lublin, Poland.

Zhao J, Ni T, Li Y, Xiong W, Ran W, Shen B, Shen Q and Zhang Q. (2014) Responses of Bacterial Communities in Arable Soils in a Rice-Wheat Cropping System to Different Fertilizer Regimes and Sampling Times. PLOS One 9: 1-11.

\section{How to cite this article:}

Carolyn Zothansiami and Dwipendra Thakuria. 2020. Effect of Burning, Cropping and Synthetic Microbial Community Inoculation on Soil Enzyme Activities in 5 Year Jhum Cycle. Int.J.Curr.Microbiol.App.Sci. 9(02): 2872-2884-. doi: https://doi.org/10.20546/ijcmas.2020.902.327 